\title{
TCOM \\ Voices in health communication - experts and expert-roles in the German news coverage of multi resistant pathogens
}

\section{Matthias Wagner, Gwendolin Gurr and Miriam Siemon}

\begin{abstract}
When it comes to complex topics in the field of health and risk communication, experts are of high importance for the credibility of a news media report. This paper examines the use of experts and their roles in the news media coverage of multi-resistant pathogens by means of a quantitative content analysis of German print and online news. A cluster analysis of the expert statements identifies three different statement frames describing different expert roles. The results show manifest patterns of selected expert sources, which points to professionalized mechanisms of selecting expert sources for news media reports.
\end{abstract}

\section{Keywords}

DOI

Multi resistant pathogens in the mass media
Health communication; Risk communication; Science and media

https://doi.org/10.22323/2.18060203

Submitted: 13th January 2019

Accepted: 8th November 2019

Published: 2nd December 2019

The use of antibiotics and the battle against multi resistant germs is one of the most pressing questions in today's medicine and international health politics. This was best evidenced at the 2017 G20 summit in Hamburg, where antibiotic resistances were put on the agenda by a broad consensus [Albrecht, 2017; Haaroff, 2017]. Additionally, the online edition of Süddeutsche Zeitung, a German well established daily newspaper, mentions the common fight against terrorism and the willingness to cooperate internationally in the case of multi resistant germs at the same time, when commenting on the outcomes of the summit. This comparison does not seem too far-fetched, considering the prognosis that multi resistant pathogens will cause 10 million deaths worldwide by 2050 , as is stated by a widely and controversially discussed study launched by the British government in 2014 [O'Neill, 2014, pp. 12-14]. This forecast seems bleak, but current figures by the German Ministry of Health, also indicate that multi resistant germs cause 10.000 to 15.000 deaths in Germany every year [German Ministry of Health, 2015].

When seeking information on health- and risk-related issues, such as antibiotic resistances, most people rely on mass media as a primary source [Dunwoody, 
2008]. One of mass media's functions in health communication - the informational function - concerns the audience's exposure to new developments in the fields of medicines and treatments as well as to inform about risks and warnings of threats, such as epidemics [Viswanath, 2015, p. 241]. Against this backdrop, it is necessary to investigate the news media coverage of antibiotic resistances as the outcome of journalistic working procedures and with regard to the point of reference for the audience.

Even beyond the context of health- and risk-related issues, the use of experts as sources in news reporting has increased in the last decades [Albaek, Christiansen and Togeby, 2003, p. 941]. Since scientific arguments and their originators are highly valued in the media coverage of risks, their investigation is of major importance [Peters, 1994, p. 162]. Previous research thereby focused on the actors' degree of expertise, their affiliation to societal groups and on aspects such as gender [e.g. Vasterman and Ruigrok, 2013; Shih, 2011; Werner et al., 2017; Ross and Carter, 2011; Magin and Stark, 2010]. The question arises as to whether these findings can be transferred to the news coverage of multi resistant pathogens.

Therefore, the purpose of the present paper is to bring into sharper focus the appearance of experts and their statements and roles in media reports on the issue of antibiotic resistances. The role of experts cited in media reports has been analyzed sufficiently [e.g. Huber, 2014; Nölleke, 2013; Kruvand, 2009; Peters, 1994]. However, only deductive methods were used, gained from qualitative surveys of journalists and theoretical concepts. This study uses inductive-quantitative content analysis as the method of choice to identify patterns in the statements that in turn point to specific expert roles. The data has been collected within the scope of the cooperative project "InfectControl 2020", which beyond research by other disciplines, aimed to analyze the role of the mass media in informing the public about the issue of multi-resistant pathogens. The period of investigation is linked to the course of the cooperative project.

This study shall investigate the extent to which various social groups and types of experts participate in the media discussion about a complex scientific medical issue with high social relevance. The subject area of multi resistant pathogens is very well suited as a research field for the use of expert sources in the mass media. At the beginning of the data collecting process, it was not yet a strongly established topic in the media. This led to the fact that it was hardly possible to fall back on already established expert sources, which, however, are required particularly frequently due to the complex topic. Moreover, it is not a controversially discussed topic, which makes the selection process of experts and their statements less dependent on different agendas. How - if at all — do these differ from structures previously identified? This is relevant also with regard to the criteria that determine the journalists' selection of experts and their statements. The leading question is thus:

Which experts dominate the reporting on multi-resistant pathogens in Germany and to what extent can manifest expert roles be identified through emerging statement frames?

In order to answer the leading research question, the definition of experts and the roles experts play in media reporting will first be addressed theoretically. Subsequently, the selection of experts from a journalistic perspective and the 
emergence of expert patterns occurring in media texts will be examined. A review of past content analyses of related topics show similar results and leads to concrete hypotheses to be tested within this study.

\section{Experts in media coverage}

\subsection{Definition of experts}

When it comes to media reports, experts are regarded as particularly influential sources [Page, Shapiro and Dempsey, 1987, p. 39]. Their expertise is most likely needed in scientific, risk and environmental reporting [Huber, 2014, pp. 32-33], where the complex medical topic of antibiotic resistance can be found. Today, however, expertise is no longer provided by scientists only. In principle, actors from all areas of society, such as (non-)profit organizations, civil societies and companies, can potentially assume the role of experts [Bogner, Littig and Menz, 2014 , p. 10]. Keeping with this, studies investigating the role of experts in the media coverage reveal the necessity to define precisely who counts as an expert, considering in each case the concrete thematic context. This is particularly important for the results to be meaningful and comparable to those of other studies.

Despite this necessity, studies dealing with the concept of experts often lack a clear definition of the term "expert". To achieve expert status, a person needs to fulfill certain requirements. First, experts need to have specific knowledge they apply to solve a problem or to make a decision. Second, this expertise must be demanded by others, for example by laypersons [Remus, 2014, pp. 223-224; Peters, 1994, p. 223]. In the case of experts in media reporting, Remus [2014] differentiates between three types of experts. Authoritative experts are those who have obtained specific knowledge or experience and receive their expert status based on their relationship to laymen. They are given the expert status by journalists. Situational experts, on the contrary, are experts only temporarily and in certain contexts chosen by journalists. Pseudo-experts are considered as experts by either themselves or a journalist, but are in fact no experts [Remus, 2014, pp. 25-26].

This study follows the definition of experts in health-related media coverage suggested by Remus [2014] — though limited. According to this definition, patients and their advocates for example, can also have an advantage in experience and knowledge compared with media recipients. In that case, they become situational experts. The same applies to other groups of actors, like politicians and affected persons, who are not primarily concerned with health issues. In opposition to that, authoritative experts are professionally concerned with health issues in their everyday lives. In this study, scientists, medical practitioners and hospital staff are considered as authoritative experts. Table 1 shows the assignment of the classified actors to expert groups (authoritative and situational).

For the purposes of this study, the categorization of pseudo-experts is irrelevant, since the selection of experts has already been carried out in journalistic practice. Thus, all sources used in the media coverage had been considered as relevant voices by journalists beforehand. 
Table 1. Experts in the German news coverage of multi resistant pathogens $(n=1391)$. Basis of the calculation: Number of cited Experts from 11/01/2016 until 10/31/2018.

\begin{tabular}{|lrr|}
\hline Group & Number & Percent \\
\hline Authoritative Experts & 912 & 65,6 \\
Scientists & 534 & 38,4 \\
Physicians/Veterinariens & 78 & 5,6 \\
Hospitals, Hygienists & 300 & 21,6 \\
Situational Experts & 479 & 34,4 \\
Politicians & 318 & 22,9 \\
Economy, Interest Groups & 97 & 7 \\
Persons affected, Public & 64 & 4,6 \\
\hline Total & 1391 & 100,0 \\
\hline
\end{tabular}

\subsection{The role of experts in journalistic practice}

Studies on journalists' contacts with scientists [Albaek, 2011, p. 340; Huber, 2014, p. 137; Schäfer et al., 2012, p. 240] show that the selection of experts is first and foremost initiated by journalists, who then determine whose voice is heard in discourse on a particular topic.

Journalists do not only decide on which actors to cite, but also on the statements to be integrated into the journalistic text. Many experts are prepared to meet exactly what is required by journalists [Nisbet, Brossard and Kroepsch, 2003, pp. 43-44]. Therefore, it does not matter, whether they are requested as a source by journalists or they provide information in the form of PR articles themselves.

Expert sources are used in journalistic texts primarily to provide facts, to increase credibility and to ensure objectivity [Boyce, 2006; Steele, 1995]. These are, however, not the only reasons why experts are cited directly or indirectly. They also shape the context of the story, are a dramaturgical component and increase the news value by highlighting threat, creating proximity or triggering controversy [Nölleke, 2013 , p. 367]. When writing news articles, journalists often prefer short and well understandable quotes to complex explanations. Experts can provide these quotes by adopting clear positions, performing alarming assessments and making demands [Peters, 1994, p. 175; Rachels, 1991, p. 67].

Experts should perform a certain function for journalists, namely to increase the quality of their article, to make its publication more likely, and to achieve a prominent placement of the article. Adapting to the rules of journalism is one of the most important prerequisites for being requested as an expert source [Peters, 1994, p. 175]. Journalists work most efficiently when knowing in advance what they want the experts to say [Nölleke, 2013, p. 328; Shoemaker and Reese, 1996, p. 131]. This presupposes that they know already the sources they intend to cite, that these are considered reliable, recommended by other colleagues or established as experts in the media business [Huber, 2014, p. 137-140; Kruvand and Goodwin, 2012, p. 578; Reinemann and Huismann, 2007, p. 480]. In journalistic practice, it is most efficient to rely on the same experts for certain topics [Goodman, 1999]. While the use of expert sources thus increases, the variance of the actors decreases [Conrad, 1999; Steele, 1995]. This form of repeated self-referencing leads to the same experts being quoted in the media text and thus the same arguments. 
Similar selection strategies and a choice of sources, which is not primarily based on substantive arguments, result inevitably in recurring patterns in the media coverage. It is plausible to assume that journalists already have certain ideas about the role and function of a particular source before requesting it for their article. Another possibility is to restructure the statements of experts by shortening and placing them in such a way that they fit their expected roles. The result of these selection and highlighting processes of certain sections of reality are frames. Journalists construct them in their media reports, so they can be found as manifest frames in the media texts [Matthes, 2014]. According to Entman [1993], they consist of problem definitions, attributions, evaluations and recommendations for solutions and actions. The concept refers to media structuring (frame building), but also to the subjective interpretation of the recipients (frame setting) [Scheufele, 2003]. In this paper, frame building is examined, and even more specifically, statement frame building, which through external statements about the cause of acts and the selection processes of the processing journalists lead to manifest statement frames in the media texts. A journalist's decisions on the selection and interpretation of specific statements by experts are decisive for a comprehensive or simplified picture of the topic [van Gorp, 2007, p. 69; Callaghan and Schnell, 2001, p. 187] and allow conclusions to be drawn about the respective role context of the expert which was assigned to him by the journalist. As a result, the news articles on multi-resistant pathogens can contain several statement frames, which in turn reflect different expert roles.

Peters [1994] identified four journalistic frames - manifest patterns in the news coverage - in which the roles of experts can be described. He distinguishes the successful scientist, the applied problem solver, the advocate of divergent positions and the defender or lawyer [1994, p. 179]. Kruvand [2009] collected the roles of actors in so-called media stories, which are comparable to frames. However, a media story does not necessarily imply to a certain role. Actors can take on different roles; they could act as advocates or legitimators, as critics or skeptics, or take on the role of arbitrators among the different opinions of other sources in the story [Kruvand, 2009, p. 35].

The method used in this study follows these assumptions of selection mechanisms and functions of expert sources, but uses an explorative method to identify expert roles. In this study, the inductive-quantitative approach of Matthes \& Kohring [2004; 2008] is used to identify expert roles. While previous studies directly capture the roles of experts as theoretical constructs, this study first collects the statements of all experts and groups them into statement frames using a cluster procedure. The statement frame then serves as an indicator of the role of the actors in the media text.

\subsection{Literature review: experts in news coverage}

The results of earlier studies in the field of health and risk communication provide more detailed indications on what kind of experts can be expected for the topic of multi resistant pathogens in German news coverage and how they can be operationalized. Therefore, studies investigating the media coverage on epidemics like the influenza A pandemic [Vasterman and Ruigrok, 2013], the West Nile virus and the avian flu [Shih, 2011] or Alzheimer's disease [Werner et al., 2017] as well as 
results on the news media coverage on health issues in general [Appel, 2000; Tanner and Friedman, 2011] were taken into account.

As stated above, when it comes to science and health-related issues, journalists particularly rely on sources when constructing news stories, as specific expertise may be required [Shih, 2011, pp. 1-2; Conrad, 1999, p. 289]. Most of the previous studies suggest that institutional actors and experts, in the more restrictive sense, account for the majority of cited sources. Accordingly, scientists appear as one of the dominant groups in most of the studies on experts in health-related media coverage [e.g. Huber, 2014, pp. 113-114; Tanner and Friedman, 2011, p. 12; Vasterman and Ruigrok, 2013, p. 446; Werner et al., 2017, p. 6]. Persons working in the medical sector also have their say, even though their opinions vary in different studies [e.g. Appel, 2000, p. 105; Huber, 2014, pp. 113-114; Tanner and Friedman, 2011, p. 12]. A reason therefore might be that some analyses take only doctors into account, while others also consider further hospital staff. Government officials, as well as health authorities like the World Health Organization (WHO) or similar institutions on the national level are among the most cited experts, too [e.g. Shih, 2011, p. 13; Tanner and Friedman, 2011, p. 12; Vasterman and Ruigrok, 2013, p. 446].

Shih [2011, pp. 17-18] explains this dominance of institutional and administrative sources not only by the nature of health issues, but also by the fact that credible and authoritative sources meet the professional requirements and routines of journalists. From her point of view, journalists tend to present health issues from a rather official and general than from an individual human point of view. This is also shown in the fact that affected persons and their friends and relatives or laypersons in general are only a minority among the cited sources [Appel, 2000, p. 105; Shih, 2011, pp. 17-20; Werner et al., 2017, p. 6].

In addition, there are statistics on the gender distribution of experts, which has not been quantitatively investigated in health communication topics to date. The huge imbalances between female and male experts are indications of a phenomenon independent of the specific topic. Regardless of time, subject and different media, several studies came to the common result that female experts are heavily underrepresented in the news coverage. The share of women as cited actors ranges from 15 to $30 \%$, while men dominate the news coverage by being cited in 70 to 85 $\%$ of the cases [Huber, 2014, p. 165; Magin and Stark, 2010, p. 393; Pallaver and Lengauer, 2008, p. 107; Ross and Carter, 2011, pp. 1158-1159]. Differences are also investigated concerning the affiliation of actors and their gender. While men are more often governmental or political actors than women, the gender imbalances of mentioned health workers in the British and Irish news media are lower [Ross and Carter, 2011, p. 1159]. Thus, the role of the cited actors' gender in the news coverage on health communication needs to be further investigated, too.

\subsection{Research questions and hypotheses}

The purpose of this study is to analyze the role of experts and their statements when it comes to the media coverage of a complex health issue, such as multi resistant germs. The central questions are thus: 
Which experts dominate reporting on multi-resistant pathogens in Germany and to what extent can manifest expert roles be identified through emerging statement frames?

The first step is to determine which experts, or more precisely, which types of experts, dominate the reporting. Previous studies on health and risk reporting produced results on the diversity of used expert sources. Whereas a high number of authoritative experts are found, the number of affected persons and laypersons are small [Huber, 2014, pp. 113-114; Vasterman and Ruigrok, 2013, p. 446; Shih, 2011, p. 17; Werner et al., 2017, p. 6]. It shall be analyzed as to whether the same applies to the issue of multi resistant pathogens testing the following hypothesis (H1): the proportion of authoritative experts is significantly higher than the proportion of situational experts in media coverage on multi-resistant pathogens in German reporting.

Studies focusing on the group of affected persons suggest that only a very small proportion of the expert statements is attributed to patients and their relatives [Appel, 2000, p. 105; Shih, 2011, p. 17-20; Werner et al., 2017, p. 6]. The hypothesis (H2) applies: affected persons are cited less often than other sources in the German media coverage of multi resistant germs.

Finally, the gender balance of cited experts has shown to be uneven in previous research [Huber, 2014, p. 165; Pallaver and Lengauer, 2008; Ross and Carter, 2011, pp. 1158-1159; Magin and Stark, 2010, p. 393]. For this reason, the hypothesis (H3) applies: the proportion of female experts in daily news coverage on multi-resistant pathogens is significantly lower than the proportion of male experts. Focusing on social groups further allows to make more specific statements about gender distribution. Differences are also investigated concerning the affiliation of actors and their gender [Ross and Carter, 2011, p. 1159]. The following hypothesis (H4) applies: there is a significant correlation between the gender of the actors and their affiliation to a social group.

\section{Method}

\subsection{Sample}

To investigate the specific research questions, a quantitative and subject-related media content analysis of selected German daily print and online media was chosen as method of inquiry.

The media reports to be analyzed were selected in a multilevel and systematic procedure. To ensure that the investigation ties in with previous research, the selection of media was based on daily news journalism. In the first step, print and online media are chosen as media forms. Since online news portals are used increasingly in addition to established print editions of daily newspapers [Hölig and Hasebrink, 2017, p. 17], they significantly influence recipients and their handling of health risks, too. ${ }^{1}$ Within these two media forms, media genres were chosen in the second step. The selection of regional print media followed their

\footnotetext{
${ }^{1}$ The same applies to daily TV news. The analysis of two main news programs (Tagesschau on $\mathrm{ARD}$ /das Erste and RTL aktuell on RTL) indicated a very small number of relevant reports, so that it assumed that the topic of multiresistant germs hardly passes the publication barrier in news programs.
} 
audience's geographical distribution in Germany. Due to the broad range of topics in online news, only news websites are considered amongst all online media. In the third step of the selection procedure, the media brands are chosen. The media were selected based on their reach; the selected news websites are amongst the ten most used news websites in Germany [Schröder, 2018]. Furthermore, each of the selected media includes a health- or knowledge-related section, yet all sections and segments were taken into account for the analysis.

Media reports from print and online media ${ }^{2}$ were retrieved from electronic databases (LexisNexis, Factiva, SZ-Archiv) from 10/31/2016 to 10/31/2018 and, subsequently, archived and coded. To minimize unintended effects, coders were assigned the reports on a rotating basis.

\subsection{Units of analysis and categories}

In the last step of the selection procedure, the media articles to be analyzed were identified among all content archived. Articles were to be analyzed, if provided, they address or at least marginally mention the issue of multi resistant germs or antibiotic resistances. This precondition was operationalized through a list of keywords, ${ }^{3}$ which comprises relevant indicators of the specific topic and had previously been tested extensively. Actors appearing in the news reports were gathered on two levels: while on the first level, the unit of report, their occurrence in the report was noted, on the second level, those actors directly or indirectly cited were surveyed. On the second level, the actors themselves are the unit of analysis.

Having cleansed the data, a total of 1419 articles are considered for the analysis. 1391 of the actors in the articles are included. Table 2 shows how the previously deducted dimensions were operationalized. While on the first level of analysis (article), technical variables and the general occurrence of actors were coded, those actors making statements were analyzed in more detail on the second level of the analysis. Their presentation in the news coverage was measured by coding their position, name and functional description. To measure the diversity of the actors cited the "affiliation of the actor" was coded, which classified each actor into a particular group, spatial responsibility and gender. This was also helpful for the subsequent distinction between authoritative experts like researches or medical stuff who are professionally concerned with the evolution of antibiotic resistant bacteria and situational experts who gain some experience based expertise in this field, too like it would be the case with affected persons. The statement elements were measured by categorical variables, as shown in Table 2 . As the values of each of these variables were deducted from preliminary qualitative analyses of the test material, the variables are very much issue-specific.

\subsection{Validity and reliability}

To test the validity of the categorical framework, a pretest was run on a random sample of 20 reports. The categorical framework proved to be applicable and

\footnotetext{
${ }^{2}$ Aachener Zeitung, B.Z., Hamburger Abendblatt, Nürnberger Nachrichten, Sächsische Zeitung, Stuttgarter Zeitung, Ostthüringer Zeitung, Frankfurter Rundschau, taz, BILD, Welt, Süddeutsche Zeitung, focus online, spiegel online, welt.de, zeit online, SZ.de.

${ }^{3}$ Keywords: "antibio", "resist", "unempfind", "krankenhauskeim".
} 
Table 2. Dimensions and their operationalization.

\begin{tabular}{|ll|}
\hline Dimension & Operationalization \\
\hline Type of Experts & Spatial Responsibility \\
& $\begin{array}{l}\text { Affiliation of the Actor/Group Membership } \\
\text { Indentification of Gender } \\
\text { Passive/Active Experts }\end{array}$ \\
Statement-Frames & \\
\hline Problem & Problem Statement \\
Evaluation of the Problem & Precise Evaluation of the Problem \\
Solution & Measures \\
Evaluation of the Solution & Precise Evaluation of the Measure \\
Demands/Responsability Attribution & Demands/Stipulations \\
& Responsability Attribution \\
\hline
\end{tabular}

definitions of values were partly adjusted. Internal validity of the analysis is thus given. A further precondition for the methodological quality of the media content analysis is to guarantee reliability of the coding instrument. To ensure this, coders were trained extensively and a standardized reliability test was carried out.

Additional analyses on 15 to 40 units of analysis proved intercoder-reliability. To test the research instrument's reliability, a total of three tests was carried out. While in the first test, the selected reports were coded, in the second, actors within each article were identified and assigned correctly to the reports. In the third part, the actors cited were coded substantively. Reliability coefficients in accordance with Holsti ranged from $\mathrm{R}=.85$ to $\mathrm{R}=.98$ and can thus attest to good quality to the coding instrument [Früh, 2015, p. 193].

\subsection{Data analysis}

Due to the exploratory research question, the data analysis procedure was chosen to be as follows. Since each news article can contain several expert sources, individual expert statements form the data basis for the cluster analysis, which is based on the inductive approach of Matthes and Kohrings for clustering frame elements [on the methodology of the inductive-quantitative approach, see Kohring and Matthes, 2002; Matthes and Kohring, 2004; Matthes and Kohring, 2008].

The advantage of the quantitative-inductive method for recording expert roles lies in the open output of the data structuring. Only after the properties and statements of an expert source have been collected were the arguments grouped according to their similarity and thus form statement frames that can finally be defined as expert roles in a media text. This increases the reliability of data collection.

To build statement frames, a two-step-cluster analysis was applied by means of SPSS. Each statement contains a problem description, an evaluation trend, solution strategies and explicit demands or blame assignments. These individual elements form a statement and do not all have to be present at every expert source. The cluster method allows for processing categorical variables by means of the Log-Likelihood Distance. Furthermore, it automatically determines the optimal number of clusters [Chiu et al., 2001, pp. 263-268]. To minimize order effects, all 
cases were randomized before calculating the clusters. Since the Likelihood-Distance measure assumes that all variables within the cluster model are independent from each other, all categorical variables were cross-calculated with each other prior to the main calculation. No strong dependencies were found between them. ${ }^{4}$

\section{Results}

\subsection{Function, gender $\mathcal{E}$ affiliation of experts}

In the German news coverage about antibiotic resistances, journalists make use of cited experts from several sectors and disciplines as shown in Table 3. Scientists form the largest group (38\%), while the healthcare sector is also well represented. Companies in the healthcare industry, hospitals, care staff and hygienists account for $22 \%$ and physicians and veterinarians $6 \%$ of experts analysed. Politicians form the second largest group of experts (23\%). Less represented are experts of interest groups, economy and health insurance funds $(7 \%)$ as well as people affected by antibiotic resistances (5\%).

Following theoretical considerations, experts in the news coverage about health communication issues can be divided into authoritative and situational experts [Remus, 2014]. Authoritative experts, who are professionally responsible for the maintenance of health, constitute the majority of cited actors $(66 \%)$, while situational experts, whose expert status is temporary and related to their advantage in experience and knowledge over the recipients, account for one third (34\%) (cf. Table 3). A chi-square fitting test shows that the observed frequencies deviate significantly from a uniform distribution (chi-square $(1, \mathrm{n}=1391)=135.41, \mathrm{p}=$ .000 ). Thus, our data support H1 claiming that the proportion of authoritative experts is significantly higher than the proportion of situational experts.

Table 3. Cited and/or mentioned experts in the news coverage of multi resistant pathogens ( $\mathrm{n}=794$, in Percent, multiple answer). Basis of the Calculation: Number of Reports with cited Experts from 11/01/2016 until 10/31/2018.

\begin{tabular}{|lrrrrrrr|}
\hline & Scientists & Politicians & $\begin{array}{c}\text { Physicians/ } \\
\text { Veterinariens }\end{array}$ & $\begin{array}{c}\text { Hospitals, } \\
\text { Hygienists }\end{array}$ & $\begin{array}{c}\text { Economy, } \\
\text { Interest } \\
\text { Groups } \\
(\mathrm{n}=253)\end{array}$ & $\begin{array}{c}\text { Persons } \\
\text { affected, } \\
\text { Public } \\
(\mathrm{n}=555)\end{array}$ & Total \\
Function & $(\mathrm{n}=432)$ & $(\mathrm{n}=334)$ & $(\mathrm{n}=254)$ & $(\mathrm{n}=327)$ & \\
\hline $\begin{array}{l}\text { mentioned } \\
\text { mentioned } \\
\text { and cited }\end{array}$ & 31,0 & 36,8 & 74,8 & 49,8 & 68,4 & 91,2 & 58,7 \\
\hline Total & 69,0 & 63,2 & 25,2 & 50,2 & 31,6 & 8,8 & 41,3 \\
\hline
\end{tabular}

Affected persons comprise by far the largest group among all groups considered, with 555 mentioned actors in 794 reports. Actors were taken into consideration for the analysis provided they are mentioned, either passively or actively, or quoted.

Affected persons appear often, but they get a chance to speak in only $9 \%$ of the cases in which they are mentioned in the report (cf. Table 4). This is the lowest share among all social groups considered. Interestingly enough medical

\footnotetext{
${ }^{4} \mathrm{CI}<.30$ for every possible cross-calculated pair of variables.
} 
practitioners, as well as veterinarians make few statements compared to their frequency of occurrence. They are quoted in only one out of four reports in which they are mentioned. The same applies to interest groups and economic experts, such as agricultural companies (32\%). Actors from the domain of politics and the medical sector, such as hospitals and hygiene staff, are given a voice in half of the reports in which they are mentioned (50-63\%). Strikingly, scientists and scientific institutions speak most frequently among all groups of actors, when mentioned in the reports $(69 \%)$.

Table 4. Experts in the German news coverage of multi resistant pathogens ( $\mathrm{n}=1391$, in Percent). Basis of the Calculation: Number of cited Experts from 11/01/2016 until 10/31/2018.

\begin{tabular}{|lrrr|}
\hline & $\begin{array}{c}\text { Print Media } \\
\text { (regional and national) } \\
(\mathrm{n}=904)\end{array}$ & $\begin{array}{r}\text { News Websites } \\
(\mathrm{n}=487)\end{array}$ & $\begin{array}{c}\text { All Media } \\
\text { Genres } \\
(\mathrm{n}=1391)\end{array}$ \\
\hline Scientists & 37,1 & 40,9 & 38,4 \\
Politicians & 21,2 & 25,9 & 22,9 \\
Physicians/Veterinariens & 6,9 & 3,3 & 5,6 \\
Hospitals, Hygienists & 22,3 & 20,1 & 21,6 \\
Economy, Interest Groups & 8,0 & 5,1 & 7,0 \\
Persons affected, Public & 4,5 & 4,7 & 4,6 \\
\hline Total & 100,0 & 100,0 & 100,0 \\
\hline
\end{tabular}

Hence, $\mathrm{H} 2$, which states that those affected are under-represented compared to other expert groups cannot be rejected, since affected persons are considerably underrepresented. However, this only applies to those actors getting a chance to speak. Considering all actors, who act passively or actively but do not make statements, affected persons clearly dominate the reports on multi resistant pathogens.

When it comes to the gender of cited experts, several studies mentioned in chapter 2.3 reach the same conclusion: across different topics and media, women are less represented as actors in the news coverage than men. Supporting H3 our data show similar findings. $72 \%$ of 789 individual experts cited are male, while only 28 $\%$ are women (cf. Table 5). A closer look at gender distribution can be achieved by dividing experts according to their affiliation to particular social groups.

Table 5. Gender of experts in the German news coverage of multi resistant pathogens $(\mathrm{n}=789$, in Percent). Basis of the Calculation: Number of cited individual Experts from 11/01/2016 until 10/31/2018.

\begin{tabular}{|lrrrrrrr|}
\hline & Scientists & Politicians & $\begin{array}{c}\text { Physicians/ } \\
\text { Veterinariens }\end{array}$ & $\begin{array}{c}\text { Hospitals, } \\
\text { Hygienists }\end{array}$ & $\begin{array}{c}\text { Economy, } \\
\text { Interest } \\
\text { Groups }\end{array}$ & $\begin{array}{c}\text { Persons } \\
\text { affected, } \\
\text { Public }\end{array}$ & $\begin{array}{c}\text { All } \\
\text { Experts }\end{array}$ \\
\hline Function & $(\mathrm{n}=289)$ & $(\mathrm{n}=182)$ & $(\mathrm{n}=68)$ & $(\mathrm{n}=156)$ & $(\mathrm{n}=60)$ & $(\mathrm{n}=34)$ & $(\mathrm{n}=789)$ \\
\hline female & 22,1 & 42,3 & 14,7 & 30,8 & 10,0 & 47,1 & 28,0 \\
male & 77,9 & 57,7 & 85,3 & 69,2 & 90,0 & 52,9 & 72,0 \\
\hline Total & 100,0 & 100,0 & 100,0 & 100,0 & 100,0 & 100,0 & 100,0 \\
\hline
\end{tabular}

The result of an $\chi^{2}$-test show a medium significance between gender and the affiliation of actors, $\chi^{2}(5)=45.71, p=.000, \varphi=0.24$. The greatest disparity is 
found between male and female among interest groups and physicians with 10-15 $\%$ female experts. Gender gaps are also found for scientists (22\% women), companies in the healthcare sector, hospitals, care staff and hygienists (31\% women). A different picture takes shape concerning political experts as well as people affected by antibiotic resistances. $42 \%$ of the politicians cited in the news coverage about antibiotic resistances are women, while in the group of affected and public actors, nearly half of the experts are female ( $47 \%)$, though this is one of the least represented groups. In summary, the hypothesis (H4) concerning the overrepresentation of male actors in the German news coverage about antibiotic resistances can be confirmed.

\subsection{Statement frames}

In addition to the structuring variables, the affiliation to a social group was also included in the description of the statement frames. This helps to identify expert roles. One outlier group consisting of 215 cases was excluded from the analysis. These actors could not be clearly assigned to any cluster. In the first frame $(\mathrm{n}=405)$ - which we call "value-free explanation frame" - it is noticeable that the statements of the cited sources are completely free of evaluations and accusations, as can be seen in Figure 1. The most frequent statements here are made by scientists and politicians. These groups are slightly overrepresented. More than half of the expert statements deal with the emergence and spread of multi-resistant germs, a further $26 \%$ deal with serious health damages up to the death of patients. These problems are rather consequences than causes of the spread of multi-resistant pathogens and are evaluated objectively and neutrally. On average, solutions are cited frequently ( $47 \%)$, and they are more likely to be seen in research $(18 \%)$ and legislation (9\%). This is not surprising, considering that these are areas in which actors from science and politics are primarily represented.

In the second statement frame, the "solution-oriented blaming frame" $(n=333)$, scientists are clearly underrepresented while actors from the health sector dominate (34\%), such as hospital administrations, nursing and hygiene personnel (see Figure 2). Physicians are most strongly represented compared to the other clusters $(7 \%)$. The same applies to interest groups such as the "German Society for Hospital Hygiene" with $12 \%$. The main focus lies on the causal problems for the spread of multi-resistant pathogens: the frequent use of antibiotics $(51 \%)$ and structural problems in the health system, such as insufficient staff and inadequate hygiene (46\%). The evaluation tendencies are relatively balanced and most likely neutral $(61 \%)$ and appeasing $(20 \%)$. The statements are clearly more solution-oriented than in the other frames and see these most likely in the practice of the daily health care: the reduction of antibiotic administration $(26 \%)$ and preventive measures in hospitals (33\%). A particularly high proportion of the statements in the second frame are attributed to debts and claims. Nearly $40 \%$ of the statements contain an explicit attribution of blame or demand to specific actors.

With 437 cases, the third statement frame is quantitatively the largest and can be characterized as "problem-oriented alarming frame". It is also structurally and relatively similar to the first one (see Figure 3). The same problems are addressed, namely the development of drug resistance (46\%), long-term health damage $(21 \%)$ and structural problems in the health care system (13\%). Scientists are the 


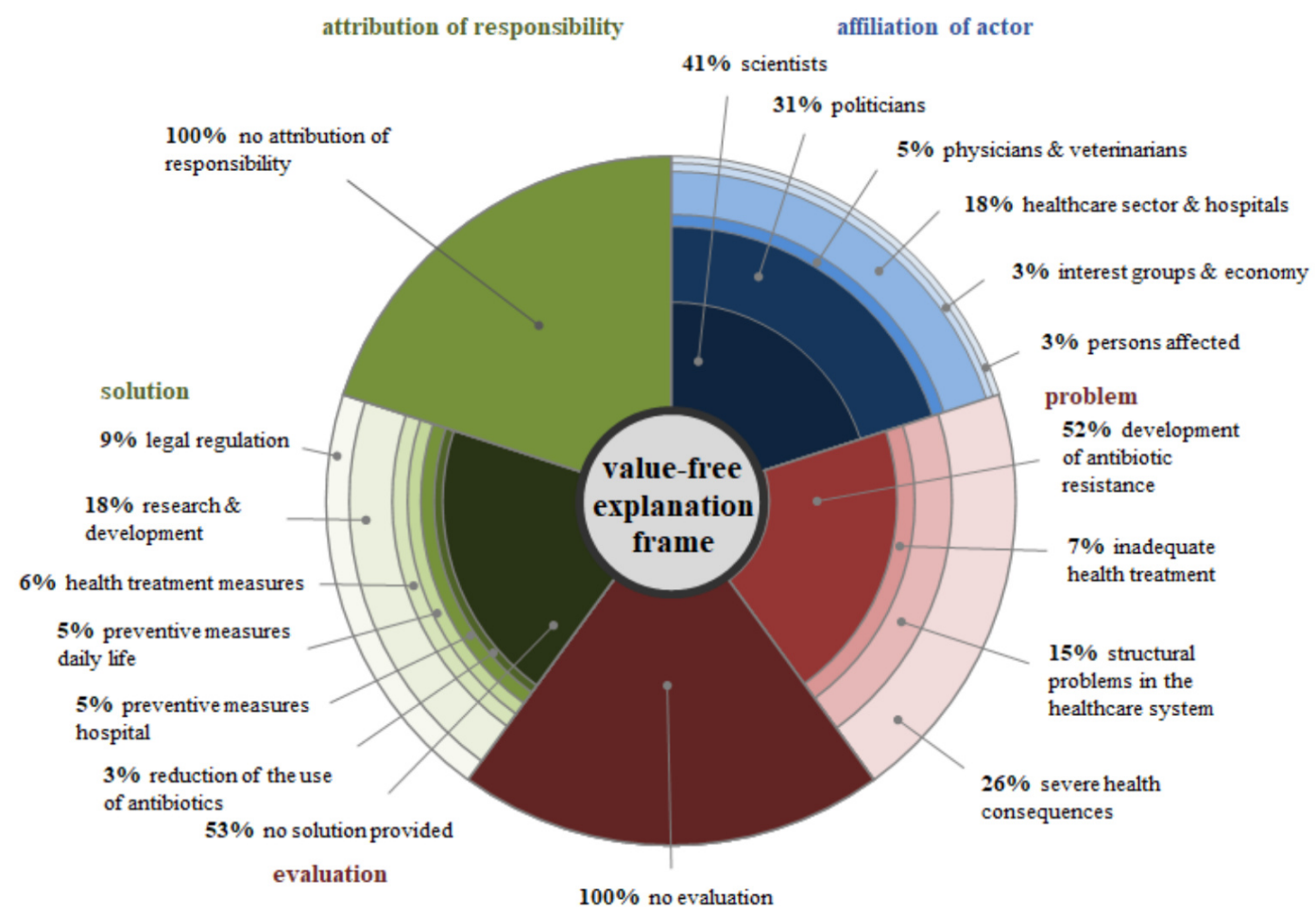

Figure 1. Clustered Statements in the news coverage of multi resistant pathogens. Valuefree explanation Frame. Basis of the calculation: Cluster analysis of 1391 experts that were quoted directly or indirectly in the German daily news coverage on multi resistant pathogens from $10 / 31 / 2016$ to $10 / 31 / 2018$.

dominant group of experts here ( $48 \%)$. The other groups are slightly underrepresented. The difference to the first statement frame lies in the tendency of the evaluation, which is the most negative across all statement frames. Almost three-quarters of all statements are alarming. The solutions presented are also most likely to be found in research (13\%) and legislation (6\%). Although three-quarters of all statements do not contain any measures at all to solve the problem.

\subsection{Conclusion on statement frames}

The argumentation structure of the three statement frames differs essentially in the tendency of the evaluation and the solution strategy. In addition, the groups of actors assigned to the statements vary in their closeness to practical health care. The first frame lacks assessments and accusations or demands of any kind. As a result, the mentioned problems also tend to remain blurred, omitting causes and concrete solution strategies. The experts in this frame argue on a factual level and remain in their respective professional context. They take on the function of explaining, without delving too deeply into the complex topic, they serve the journalist as a competent reference.

The role of the experts in the third statement frame is completely different, although the first and third frames are structurally very similar. The difference lies in the tendency towards negative evaluation and the lack of solutions. The 


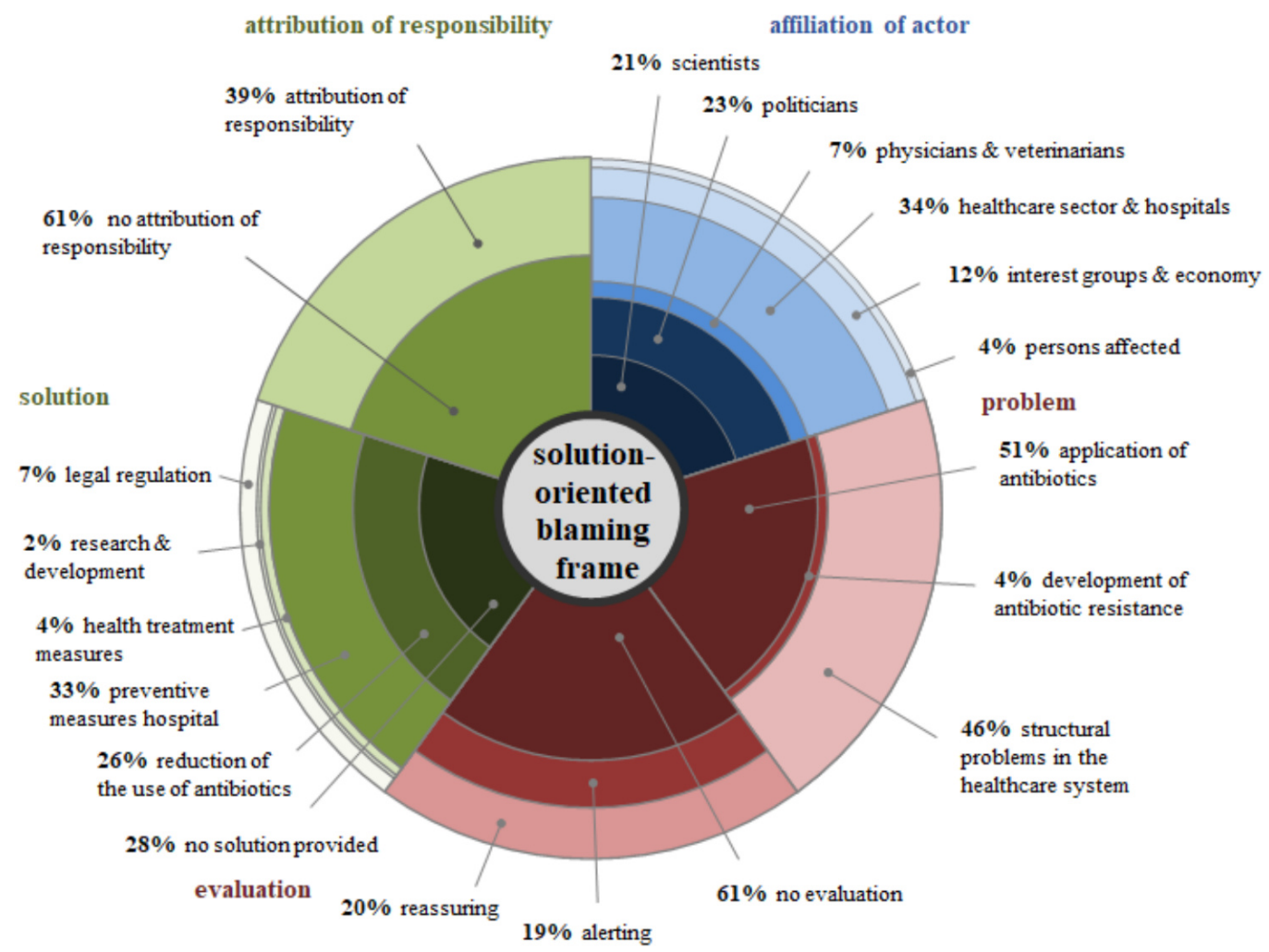

Figure 2. Clustered Statements in the news coverage of multi resistant pathogens. Solutionoriented blaming Frame. Basis of the calculation: Cluster analysis of 1391 experts that were quoted directly or indirectly in the German daily news coverage on multi resistant pathogens from $10 / 31 / 2016$ to $10 / 31 / 2018$.

distribution of expert groups is similar; the main actors are scientific. They also remain vague and give the problem an alarming tone. Due to the unspecific problems and the lack of solution strategies and demands, the alarming tendency is even more prominent. The actors offer a similar level of expertise as in the first frame, but are warning and far less neutral. They serve as admonishers to legitimize the negativity of a message.

The second pattern of argumentation, on the other hand, is structurally very different from the other two frames. Here, concrete causes for the spread and development of multi-resistant pathogens are named. These are assessed as neutral to relativizing, i.e. as a minor problem. Solutions in the field of practical health care are often presented and concrete demands are made on political representatives and the health system. Actors with these statements mainly come from the practical health sector. They accuse or defend institutions and strategic or political decisions.

These three inductive-quantitative argumentation patterns thus represent different roles in a journalistic text. The analysis suggests that, at least in the thematic context studied, recurrent, identical patterns and thus manifest functions in journalistic practice can be found. 


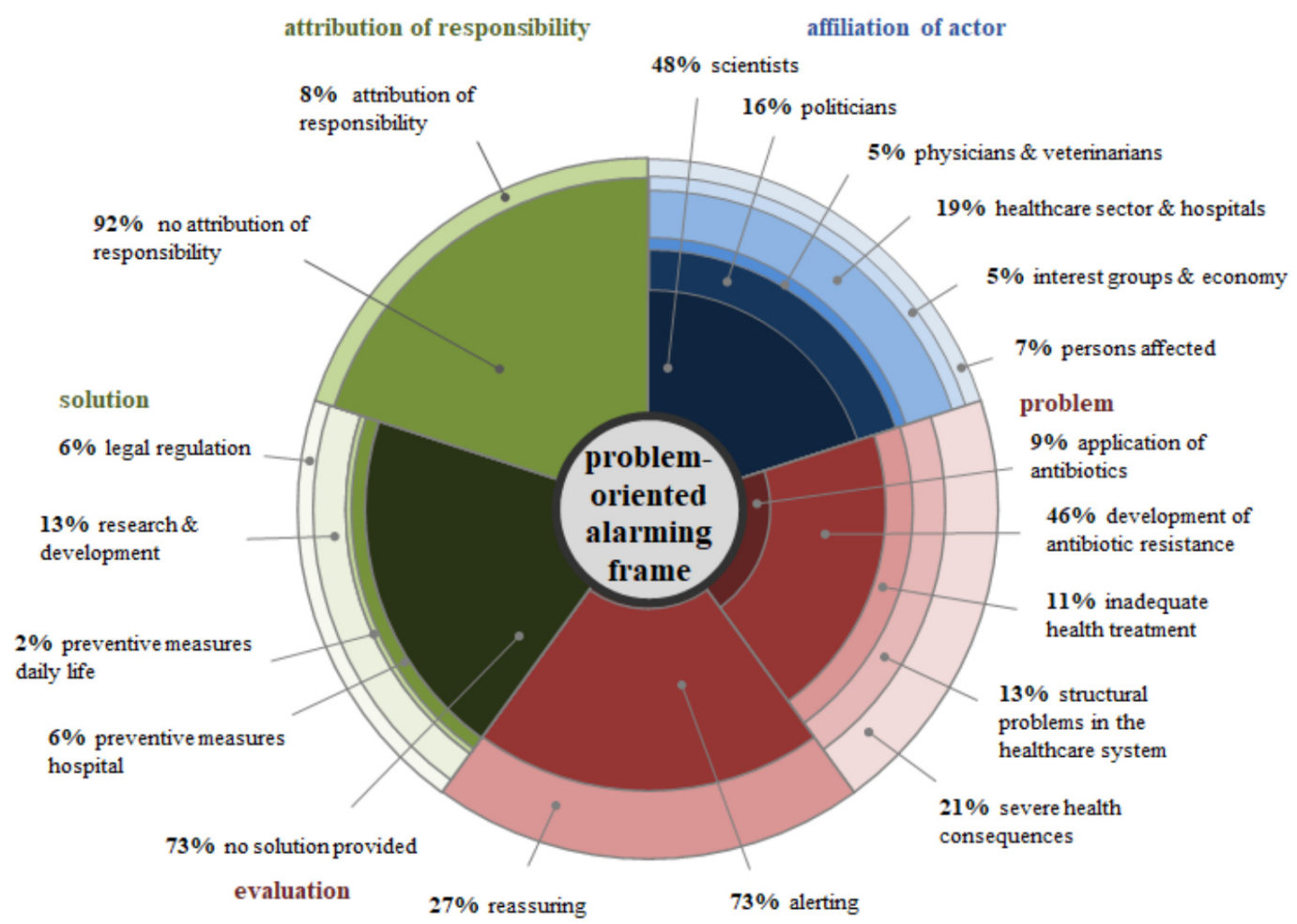

Figure 3. Clustered Statements in the news coverage of multi resistant pathogens. Problemoriented alarming Frame. Basis of the calculation: Cluster analysis of 1391 experts that were quoted directly or indirectly in the German daily news coverage on multi resistant pathogens from $10 / 31 / 2016$ to $10 / 31 / 2018$.

This study assumes that journalists have a system-specific understanding of expert sources in risk and health reporting, to which the topic of multi-resistant pathogens belongs, that is reflected in selection and presentation decisions. The results show where the selection process ends and which statements are made by which experts. These sources were described and typologized. The typologization was not only done by the passive properties of the sources, also the statements could be summarized to statement frames.

The expert sources in the field of multi-resistant pathogens are similar to those of other topics in the fields of health-, science- and risk-reporting. Overall, authoritative experts dominate reporting on multi-resistant bacteria. The strong presence of the social elite in the news coverage has two main causes. On the one hand, these groups have the resources, knowledge and interest to work with journalists. For some actors, public relations is simply part of the profession. On the other hand, they are more perceived as experts by the media because, as described in Chapter 2.1, they have the expertise to solve problems or have the power to make decisions. With experts who are used to dealing with the press, the workload for journalists is much lower, as it is not enough simply to provide a certain expertise. This also explains the relatively small proportion of physicians cited in the articles, although this is one of the most frequently occurring passive groups of actors in the news coverage and is one of the authoritative experts. However, physicians usually do not engage in public relations work and seldom focus on statements that have an impact on the media. 
The over-representation of certain expert groups in the German news media can be explained by the processes of source selection in journalistic practice. This selection is part of an efficient and resource-saving way of working. When searching for expert opinions, journalists to a large extent, resort to press releases [Baerns, 1991, p. 47], or use already known and established sources from which they already know what to expect [Nölleke, 2013; Shoemaker and Reese, 1996]. Situational experts, such as those affected and their relatives, have hardly any chance of being heard in current reporting.

The similar applies to the gender of the actors. It turned out that female experts are clearly underrepresented compared to male ones. There are different explanations for the under-representation of female actors [structural theoretical approaches can be found: e.g. Fröhlich, Peters and Simmelbauer, 2005, p. 13]. According to journalists, women are more critical of their own expertise and are less frequently found in high academic positions than their male colleagues [Huber, 2014, p. 165]. In the case of physicians, however, this explanation does not go far enough, because while in reality the gender distribution in this profession is relatively balanced [Bundesärztekammer, 2016, p. 5], male physicians are clearly overrepresented in the media. So men are more willing to appear in the media as experts and accept the rules of journalism, or journalists tend to accept men rather than women as expert sources.

Part of the gender inequality can be explained by the different social groups of expert sources. The authoritative experts, such as scientists and doctors, have a significantly lower proportion of women than the situational experts, such as those affected and their relatives. The fact that the same experts are cited again and again reinforces this effect and thus systematically prevents women from obtaining the same proportion of expert sources in reporting and from being perceived by the public as equal experts.

As Nölleke [2013, pp. 328-329] also states, journalists often know in advance the position of the actor and his role to be played in their news coverage. Thus, they are used purposefully in order to achieve the intended dramaturgy of an article or to increase the news value. However, it should be noted that the statement remains limited. Finally, the content analysis does not provide conclusive information as to whether an article was composed from the expert's contribution or whether an article was found for an intended dramaturgy [Nölleke, 2013, p. 344]. In the present study, the role of the actor was defined via its statement frame. This method has the decisive advantage of reliability and transparency over a purely deductive recording of the role in the media text, as described in Chapter 3.4. Nevertheless, it must be mentioned that the sample period of 24 months was long enough to generate an adequate number of relevant cases for multivariate analysis. However, the number of cases for the individual values of the variables was rather small, resulting in less differentiated results. Clustering was achieved using an efficient method for particularly large data sets, which is suitable for grouping variables of different scales. It could be shown empirically that the statements in the text show a low variance and differ in the argumentation in only a few variables. This results in three manifest statement frames that allow conclusions to be drawn about the different roles of the experts: 
The "value-free explanation frame" is suitable for experts who assume the role of a neutral and recognized expert. The "solution-oriented blaming frame" points to two different roles, that of defender and prosecutor. Experts who appear in the "problem-oriented alarming frame" can finally be defined as agitators. The data obtained from content analysis support the assumption of previous studies that experts play a role intended for them in a dramaturgical construct. However, although these assumptions remained limited to possible strategies of journalists and were deductively collected, they are consistent with the patterns identified here. The similarity of the expert roles identified here and the roles in previous analyses [Peters, 1994, p. 179; Kruvand, 2009, p. 35] points to professional and very stable selection mechanisms of journalists.

At the level of statements, they do not show a strong focus on semantic, but a strong focus on functional aspects in the selection of actors. The statement frames of the cited sources leave little doubt that certain roles are applied again and again. It is not just about who says something, it is about how it is said and how it fits into the journalist's concept. Experts thus increase their chances of publication if they not only reveal their specialist knowledge, but also give an assessment of the threat, assign blame and make demands. This is particularly evident in the distinction between the "value-free explanation frame" and the "problem-oriented alarming frame". These are almost congruent in most categories. They differ only in the degree of evaluation and thus have completely different roles in a journalistic article. Since the selection of expert statements is primarily the responsibility of the journalist, the possibility of instrumental functionalization of an expert is also given here. Whether this is done consciously or through constant repetition and orientation of manifest expert functions within and outside the respective publication process cannot be clarified in this study. This methodically guided inductive-quantitative definition of experts in German news reporting can now be tested in further studies for its consistency and generalizability.

Nölleke [2013, p. 367] talks of a separate news factor for experts, but there is some evidence that expert sources increase the news value, but primarily reinforce existing and classic factors such as proximity, identification and valence. These factors can be relatively easily controlled by certain selection and presentation decisions on the part of journalists. It seems evident that the criteria for the selection of experts and their statements are more functionally driven, i.e. follow the strategic goals of the journalists than convey complex topics to the general public through specialist knowledge. This has a direct impact on media practice. Experts with less media experience will be more sceptical about further cooperation with journalists if they see themselves and their statements distorted. This can in turn lead to a reduction in the selection of sources for future content if the experts do not adapt to editorial requirements. Although the role of journalists includes the simplification of complex content, the system-specific understanding of the experts in the media leads to a different knowledge reality of specific topics, which may be discussed completely differently in the professional world. This bias could be investigated by comparing statement frames in trade journals with those in the mass media in a future study. At this point a distortion can only be suspected.

In mass media news coverage, a reduction of experts to their mere function and the over-representation of social groups with certain characteristics means a fundamental weakening of diversity and transparency in reporting [e.g. Ruß-Mohl, 
2005; Haas and Lojka, 1998]. This leads primarily to a reduction in quality, because the actual goal of increasing objectivity in an article by citing experts is undermined by the repeated use of the same experts and the establishment of roles [Steele, 1995, p. 809].

For media practice, these results primarily offer opportunities for influencing current reporting. As already mentioned above, it is important for external experts to adhere to the rules of journalists in order to gain a voice in established mass media. Knowing the selection and presentation criteria of journalists is a great advantage in disseminating one's own agenda. Of course, this can be problematic, because scientific sources in particular may give up their commitment to objectivity in favour of media attention. But it is precisely in the case of a topic with danger potential that it is necessary to weigh up here whether leaving scientific objectivity by means of evaluations or blaming in order to gain greater attention is ethically justifiable. Last but not least, however, this leads to greater uncertainty among recipients and can result in a disregard for entire expert groups if certain actors particularly frequently highlight offensive threats or appear inflationarily in the media.

The results suggest that similar requirements in journalism may lead to similar expert roles and characteristics in the news coverage, regardless of country and genre boundaries. However, the method used here does not allow to claim representativeness for the media in Germany. However, the results based on the media sample are significant for the media coverage of multi-resistant germs during the study period.

Changing technological and economic conditions, the demands of the public, such as increased scepticism towards established media, and the increasing specialisation of areas of knowledge, make dealing with experts in the mass media a complex field of research with increasing relevance.

Albaek, E. (2011). 'The interaction between experts and journalists in news journalism'. Journalism 12 (3), pp. 335-348.

Albaek, E., Christiansen, P. M. and Togeby, L. (2003). 'Experts in the mass media: researchers as sources in Danish daily newspapers, 1961-2001'. Journalism $\mathcal{E}$ Mass Communication Quarterly 80 (4), pp. 937-948. https://doi .org/10.1177/107769900308000412.

Albrecht, H. (2017). 'Krankheiten kennen keine Grenzen. Ebola, Tuberkulose, resistente Keime: Was der Bundesgesundheitsminister Hermann Gröhe gegen weltweite Seuchen tun will'. [There are no limits to diseases. Ebola, tuberculosis and resistant germs: what the federal minister of health, Hermann Gröhe, aims to do about worldwide pandemics]. Die Zeit 21, p. 33. URL: https : //www . zeit .de/2017/21/g20-gesundheitsministerium-ebola-tuberkulose.

Appel, A. J. (2000). ‘Patentrezepte per TV. Die Gesundheits- und Krankheitsvorstellungen in einschlägigen Informations- und Ratgebersendungen des deutschen Fernsehens'. [Panacea by TV. Ideas of health and diseases in relevant information and advice programs]. In: Gesundheitskommunikation. [Health communication]. Ed. by D. Jazbinsek. Wiesbaden, Germany: VS Verlag für Sozialwissenschaften, pp. 96-114. https://doi.org/10.1007/978-3-663-08098-5_5. 
Baerns, B. (1991). Öffentlichkeitsarbeit Oder Journalismus? Zum Einfluß Im Mediensystem. [Public relations or journalism? The influence in the media system]. 2nd ed. Cologne, Germany: Verl. Wiss. und Politik.

Bogner, A., Littig, B. and Menz, W. (2014). 'Wer ist ein Experte?

Wissenssoziologische Grundlagen des Expertinneninterviews'. [Who is an expert? Sociological foundations of the expert interview]. In: Interviews mit Experten. Eine praxisorientierte Einführung. [Interviews with experts. A practice-oriented introduction]. Ed. by A. Bogner, B. Littig and W. Menz. Wiesbaden, Germany: Springer Fachmedien Wiesbaden, pp. 9-15. https://doi.org/10.1007/978-3-658-08349-6_2.

Boyce, T. (2006). 'Journalism and expertise'. Journalism Studies 7 (6), pp. 889-906. https://doi.org/10.1080/14616700600980652.

Bundesärztekammer (2016). Ärztestatistik zum 31. Dezember 2016. [Physician statistics as at 31 December 2016].

URL: https://www . bundesaerztekammer.de/fileadmin/user_upload/downloa ds/pdf-Ordner/Statistik2016/Stat16AbbTab .pdf (visited on 21st August 2019).

Callaghan, K. and Schnell, F. (2001). 'Assessing the democratic debate: how the news media frame elite policy discourse'. Political Communication 18 (2), pp. 183-213. https://doi.org/10.1080/105846001750322970.

Chiu, T., Fang, D., Chen, J., Wang, Y. and Jeris, C. (2001). 'A robust and scalable clustering algorithm for mixed type attributes in large database environment'. In: Proceedings of the seventh ACM SIGMOD international conference on knowledge discovery and data mining (San Francisco, CA, U.S.A.), pp. 263-268.

Conrad, P. (1999). 'Uses of expertise: sources, quotes and voice in the reporting of genetics in the news'. Public Understanding of Science 8 (4), pp. 285-302. https://doi.org/10.1088/0963-6625/8/4/302.

Dunwoody, S. (2008). 'Science journalism'. In: Handbook of Public Communication of Science and Technology. Ed. by M. Bucchi and B. Trench. London, U.K. and New York, U.S.A.: Routledge, pp. 15-26.

Entman, R. M. (1993). 'Framing: Toward Clarification of a Fractured Paradigm'. Journal of Communication 43 (4), pp. 51-58. https://doi.org/10.1111/j.1460-2466.1993.tb01304.x.

Fröhlich, R., Peters, S. B. and Simmelbauer, E. (2005). Public Relations. Daten und Fakten der geschlechtsspezifischen Berufsfeldforschung. [Data and facts on gender-specific occupational research]. Munich, Germany and Vienna, Austria: Oldenbourg.

Früh, W. (2015). Inhaltsanalyse: Theorie und Praxis. [Content analysis. Theory and practise]. Konstanz and Munich, Germany: UVK.

German Ministry of Health (2015). 10-Punkte-Plan zur Bekämpfung resistenter Erreger. [10-point plan to combat resistant pathogens].

URL: http://www . bundesgesundheitsministerium.de/ministerium/meldunge n/2015/10-punkte-plan-zu-antibiotika-resistenzen.html\#c102889 (visited on 21st August 2019).

Goodman, K. K. W. (1999). 'Philosophy as news: bioethics, journalism and public policy'. The Journal of Medicine and Philosophy 24 (2), pp. 181-200. https://doi.org/10.1076/jmep.24.2.181.2533. 
Haaroff, H. (5th July 2017). 'Die nächste Pandemie kommt mit Sicherheit'. [The next pandemic is a sure thing]. taz, die tageszeitung.

Haas, H. and Lojka, K. (1998). 'Qualität auf dem Prüfstand. Bedingungen einer kommunikativen Leistungsdiagnostik für Journalismus und Öffentlichkeitsarbeit'. [Quality on the test bench. Conditions of communicative performance diagnostics for journalism and public relations]. In: Journalismus als Kultur. Analysen und Essays. [Journalism as culture. Analyses and essays]. Ed. by W. Duchkowitsch, F. Hausjell, W. Hömberg, A. Kutsch and I. Neverla. Opladen and Wiesbaden, Germany: Westdeutscher Verlag, pp. 115-132. https://doi.org/10.1007/978-3-322-87316-3_10.

Hölig, S. and Hasebrink, U. (2017). Reuters Institute: 'Digital News Survey 2017. Ergebnisse für Deutschland'. [Results for Germany]. Arbeitspapiere des Hans-Bredow-Instituts 42. Hamburg, Germany: Hans-Bredow-Institut für Medienforschung an der Universität Hamburg.

URL: https://www . hans-bredow-institut.de/uploads/media/Publikationen /cms/media/2d87ccdfc2823806045f142bebc42f5f039d0f11.pdf.

Huber, B. (2014). Öffentliche Experten. Über die Medienpräsenz von Fachleuten. [Public experts. On the media presence of specialists]. Wiesbaden, Germany: Springer VS.

Kohring, M. and Matthes, J. (2002). 'The face(t)s of biotech in the nineties: how the German press framed modern biotechnology'. Public Understanding of Science 11 (2), pp. 143-154. https://doi .org/10.1088/0963-6625/11/2/304.

Kruvand, M. (2009). 'Bioethicists as expert sources in science/medical reporting'. Newspaper Research Journal 30 (3), pp. 26-41. https://doi.org/10.1177/073953290903000303.

Kruvand, M. and Goodwin, J. (2012). "Dr. Soundbite": the making of an expert source in science and medical stories'. Science Communication 34 (5), pp. 566-591. https://doi.org/10.1177/1075547011434991.

Magin, M. and Stark, B. (2010). 'Mediale Geschlechterstereotype. Eine ländervergleichende Untersuchung von Tageszeitungen'. [Media gender stereotypes. An international comparative analysis of newspapers]. Publizistik 55, pp. 383-404.

Matthes, J. (2014). 'Framing'. In: Konzepte: Ansätze der Medien- und Kommunikationswissenschaft. [Concepts: approaches in media and communication studies]. Baden-Baden, Germany: Nomos.

Matthes, J. and Kohring, M. (2004). 'Die empirische Erfassung von Medien-Frames'. [The empirical analysis of media frames]. Medien $\mathcal{E}$ Kommunikationswissenschaft 52 (1), pp. 56-75. https://doi .org/10.5771/1615-634x-2004-1-56.

Matthes, J. and Kohring, M. (2008). 'The content analysis of media frames: toward improving reliability and validity'. Journal of Communication 58 (2), pp. 258-279. https://doi.org/10.1111/j.1460-2466.2008.00384.x.

Nisbet, M. C., Brossard, D. and Kroepsch, A. (2003). 'Framing science: the stem cell controversy in an age of press/politics'. The International Journal of Press/Politics 8 (2), pp. 36-70. https://doi.org/10.1177/1081180x02251047.

Nölleke, D. (2013). Experten Im Journalismus: Systemtheoretischer Entwurf und empirische Bestandsaufnahme. [Experts in journalism: systems theoretical design and empirical inventory]. Baden-Baden, Germany: Nomos. 
O'Neill, J. (2014). Review on antimicrobial resistance. antimicrobial resistance: tackling a crisis for the health and wealth of nations. URL: https: //amr-review.org/sites/d efault/files/AMR $\% 20$ Review $\% 20$ Paper $\% 20-\% 20$ Tackling $\% 20 \mathrm{a} \% 20$ crisis $\% 20$ for $\% 20$ the $\% 20$ health $\% 20$ and $\% 20$ wealth\%20of\%20nations_1.pdf (visited on 21st August 2019).

Page, B. I., Shapiro, R. Y. and Dempsey, G. R. (1987). 'What moves public opinion?' American Political Science Review 81 (1), pp. 23-43. https://doi.org/10.2307/1960777.

Pallaver, G. and Lengauer, G. (2008). 'Weibliche Repräsentanz und Media Frames'. [Female representation and media frames]. In: Medien - Politik - Geschlecht. [Media - Politics — Gender]. Ed. by J. Dorer, B. Geiger and R. Köpl. Wiesbaden, Germany: Springer VS. https://doi.org/10.1007/978-3-531-91096-3_8.

Peters, H. P. (1994). 'Wissenschaftliche Experten in der öffentlichen Kommunikation über Technik, Umwelt und Risiken'. [Scientific experts in public communication of technology, environment and risks]. Kölner Zeitschrift für Soziologie und Sozialpsychologie 46 (Special issue), pp. 163-190.

Rachels, J. (1991). 'When philosophers shoot from the hip'. Bioethics 5 (1), pp. 67-71. https://doi.org/10.1111/j.1467-8519.1991.tb00145.x.

Reinemann, C. and Huismann, J. (2007). ‘Beziehen sich Medien immer mehr auf Medien? Dimensionen, Belege, Erklärungen'. [Do media refer more and more to media? Dimensions, evidence, explanations]. Publizistik 52 (4), pp. 465-484. https://doi.org/10.1007/s11616-007-0243-3.

Remus, N. (2014). 'Experten als Qualitätsgarant im Gesundheitsjournalismus? Der Einsatz medialer Experten als Qualitätsindikator im gesundheitsjournalistischen Informations- und Berichterstattungsprozess'. [Experts as quality guarantor in health kournalism? The use of medial experts as quality indicator in the information and news coverage process in health-related journalism]. In: Qualität im Gesundheitsjournalismus. Perspektiven aus Wissenschaft und Praxis. [Quality in health journalism. Perspectives from science and practice]. Ed. by V. Lilienthal, D. Reineck and T. Schnedler. Wiesbaden, Germany: Springer VS, pp. 217-239. https://doi.org/10.1007/978-3-658-02427-7_12.

Ross, K. and Carter, C. (2011). 'Women and news: a long and winding road'. Media, Culture E Society 33 (8), pp. 1148-1165. https://doi.org/10.1177/0163443711418272.

Ruß-Mohl, S. (2005). 'Qualität'. [Quality]. In: Handbuch Journalismus und Medien. [Journalism and Media Handbook]. Reihe Praktischer Journalismus. Vol. 60. Konstanz, Germany: UVK, pp. 374-381.

Schäfer, M. S., Ivanova, A., Schlichting, I. and Schmidt, A. (2012). 'Mediatisierung: Medienerfahrungen und -orientierungen deutscher Klimawissenschaftler'. [Mediatization: media experiences and orientations of German climate scientists]. In: Das Medien-Klima. Fragen und Befunde der kommunikationswissenschaftlichen Klimaforschung. [The media climate. Questions and findings of climate research in communication science]. Ed. by I. Neverla and M. S. Schäfer. Wiesbaden, Germany: Springer VS, pp. 233-252. 
Scheufele, B. (2003). Frames — Framing — Framing-Effekte. Theoretische und methodische Grundlegung des Framing-Ansatzes sowie empirische Befunde zur Nachrichtenproduktion. [Frames - Framing — Framing effects. Theoretical and methodical foundation of the framing approach as well as empirical findings on news production]. Wiesbaden, Germany: Westdeutscher Verlag. https://doi.org/10.1007/978-3-322-86656-1.

Schröder, J. (8th February 2018). ‘IVW-News-Top-50: Deutsche Online-Nachrichtenangebote so populär wie nie zuvor — Visits-Rekorde für Bild, upday, Welt, Zeit, stern und F.A.Z.' [German online news offers more popular than ever before - business records for Bild, upday, Welt, Zeit, stern and F.A.Z.] MEEDIA. URL: https://meedia.de/2018/02/08/ivw-news-top-50 -deutsche-online-nachrichtenangebote-so-populaer-wie-nie-zuvor-visi ts-rekorde-fuer-bild-upday-welt-zeit-stern-und-f-a-z/.

Shih, T. J. (2011). 'News construction, news sources and epidemic hazards. News coverage of public health risk issues: The role of news sources and the process of news construction'. International Public Health Journal 3 (1), pp. 1-32.

Shoemaker, P. J. and Reese, S. D. (1996). Mediating the message: theories of influences on mass media content. White Plains, NY, U.S.A.: Longman.

Steele, J. E. (1995). 'Experts and the Operational Bias of Television News: The Case of the Persian Gulf War'. Journalism \& Mass Communication Quarterly 72 (4), pp. 799-812. https://doi.org/10.1177/107769909507200404.

Tanner, A. and Friedman, D. B. (2011). 'Authorship and information sourcing for health news on local TV web sites: an exploratory analysis'. Science Communication 33 (1), pp. 3-27. https://doi .org/10.1177/1075547010364926. van Gorp, B. (2007). 'The constructionist approach to framing: bringing culture back'. Journal of Communication 57 (1), pp. 60-78.

Vasterman, P. L. M. and Ruigrok, N. (2013). 'Pandemic alarm in the Dutch media: media coverage of the 2009 influenza A (H1N1) pandemic and the role of the expert sources'. European Journal of Communication 28 (4), pp. 436-453. https://doi.org/10.1177/0267323113486235.

Viswanath, K. (2015). 'Health communication'. In: The concise encyclopedia of communication. Ed. by W. Donsbach. Malden, MA, U.S.A.: John Wiley \& Sons Inc.

Werner, P., Schiffman, I. K., David, D. and Abojabel, H. (2017). 'Newspaper coverage of Alzheimer's disease: comparing online newspapers in Hebrew and Arabic across time'. Dementia 18 (4), pp. 1554-1567. https://doi.org/10.1177/1471301217717062.

Authors

Matthias Wagner is Research Assistant in the InfectControl2020 media monitoring project at Freie Universität Berlin and project manager at Goefak Medienforschung $\mathrm{GmbH}$. He is responsible for empirical studies on practical problems in the media sector. E-mail: Matthias.Wagner2@fu-berlin.de. 
Gwendolin Gurr currently works as research assistant at the Department of Media and Communication Research at the University of Fribourg, Switzerland. She received her Master's degree in Media and Political Communication at Freie Universität Berlin. Within an SNSF-Project, she currently researches the phenomenon of issue disenchantment, which lies in the fields of political communication, media effects and media use research.

E-mail: gwendolin.gurr@unifr.ch.

Miriam Siemon, BA in Communication- and Social Sciences at the University of Erfurt (2015). Currently MA student in the Media and Political Communication program at Freie Universität Berlin and student assistant in the InfectControl2020 media monitoring project, which is analyzing the German news coverage about multi-resistant pathogens. E-mail: miriam.siemon@fu-berlin.de.

Wagner, M., Gurr, G. and Siemon, M. (2019). 'Voices in health communication - experts and expert-roles in the German news coverage of multi resistant pathogens'. JCOM 18 (06), A03. https://doi.org/10.22323/2.18060203. 